\title{
EVALUATION OF KNOWLEDGE ABOUT PRIMARY IMMUNODEFICIENCIES AMONG POSTGRADUATE MEDICAL STUDENTS
}

\author{
Oksana BOYARCHUK ${ }^{1}$, Maria KINASH ${ }^{1}$, Tetiana HARIYAN ${ }^{1}$, Tetiana BAKALYUK ${ }^{2}$ \\ ${ }^{1}$ Department of Children's Diseases and Pediatric Surgery, I. Horbachevsky Ternopil State Medical \\ University, Ukraine \\ ${ }^{2}$ Department of Medical Rehabilitation, I. Horbachevsky Ternopil State Medical University, Ukraine \\ Received 29 Sept 2018, Accepted 08 Nov 2018 \\ https://doi.org/10.31688/ABMU.2019.54.1.18
}

\begin{abstract}
Introduction. An early diagnosis of primary immunodeficiencies (PID) prevents the development of complications and improves the quality of life of children with PID. A large number of PID are undiagnosed or misdiagnosed. An important challenge is improving the awareness of physicians about these diseases.

The objective of the study was to evaluate the knowledge about primary immunodeficiencies among postgraduate medical students of different specialties. Methods. A survey among postgraduate medical students of different specialties on awareness of PID was conducted. The study involved postgraduate medical students (interns) of I. Horbachevsky Ternopil State Medical University, Ukraine. There were 93 participants: 17 pediatricians, 27 general practitioners / family (GP/F) physicians, 39 internists, 10 surgeons. The survey consisted of a questionnaire containing 25 questions.
\end{abstract}

Results. The average percentage of correct answers given by the surveyed postgraduate medical students was $63.6 \%$, and ranged from $24.7 \%$ to $91.4 \%$. The highest level of knowledge was demonstrated among

\section{Résumé}

Lévaluation des connaissances des médecins résidents concernant les immunodéficiences primaires

Introduction. Le diagnostic précoce des immunodéficiences primaires (IDP) prévient le développement de complications et améliore la qualité de la vie des enfants avec les IDP. Nombre de IDP sont non diagnostiquées ou diagnostiquées incorrectement.

Laugmentation de la compétence des médecins sur ce problème est très importante.

L'objet de l'étude était l'évaluation des connaissances des médecins résidents des professions médicales de différentes spécialités sur les immunodéficiences primaires. Méthodes. Des médecins résidents de différentes spécialités ont été interrogés sur leurs compétences concernant l'IDP. Les médecins résidents de l'Université Médicale d'Etat de Ternopil de I. Horbatchevski, Ukraïne ont participé à cette recherche. Il y avait 93 participants, y compris 17 pédiatres, 27 médecins de la pratique générale en médecine familiale (PGMF), 39 thérapeutes, 10 chirurgiens. L'enquête a prévu les réponses à 25 questions spécialement préparées. 
pediatricians (76.9\%). The lowest knowledge was revealed concerning the specific signs of PID, in particular verification of ataxia-telangiectasia and management of Nijmegen breakage syndrome. The percentage of correct answers about warning signs of PID in children was $88.2 \%$ among pediatricians and $63.5 \%$ among internists.

Conclusions. The study has shown insufficient knowledge about PID among postgraduate medical students of different specialties. Identified weaknesses in educating and training of postgraduate medical students about PID will help to enhance the educational programs that may benefit of early diagnosis, patient's management and improve quality of life of children with PID.

Keywords: primary immunodeficiencies, postgraduate medical students' awareness, pediatricians.

\section{Abbreviations:}

PID - primary immunodeficiencies

GP/F - general practitioners / family

CVID - Common Variable Immunodeficiency

AFP - alpha-fetoprotein

NBS - Nijmegen breakage syndrome

WBC - White Blood Cells

A-T - ataxia-telangiectasia

\section{INTRODUCTION}

The diagnosis of rare diseases can cause difficulties for physicians of all specialties. Primary immunodeficiencies (PID) belonged to rare diseases until recently, although data from the literature indicate that $1-2 \%$ of the population may be affected with PID PI, $^{1,2}$ Today, we know more than 350 diseases that belong to PID and their number is growing every year ${ }^{3}$. The clinical picture of PID is very variable ${ }^{4}$, which also makes difficulties in diagnosis. PID are characterized by severe recurrent infections, autoimmunity, allergy and malignancy.

The early diagnosis of PID prevents the development of complications and improves the quality of life in children with PID $^{2,3}$. Therefore, physicians and interns' awareness of the early diagnosis of PID is extremely important ${ }^{5,6}$. The problem of early PID diagnosis is relevant worldwide, especially in countries with poor access to high-quality immunological and genetic testing?

Improvements in molecular diagnosis, genetic sequencing and treatment lead to improving patients' quality of life, reducing morbidities and mortalities related to PID 3 . In Ukraine, despite the significant achievements in diagnosis of PID, the situation
Résultats. Le pourcentage moyen de réponses correctes reçues de la part des médecins résidents interrogés était de $63,6 \%$ et variait de $24,7 \%$ à $91,4 \%$. Les pédiatres ont montré le plus haut niveau de connaissances de 76,9\%. Les plus bas niveaux des connaissances ont été déterminés en ce qui concerne les caractéristiques spécifiques de l'IDP, en particulier des problèmes d'ataxie-télangiectasie et du traitement du syndrome de Nimègue. Le pourcentage de réponses correctes concernant les signes d'avertissement de l'IDP chez les enfants était de 88,2\% parmi les pédiatres et de 63,5\% parmi les médecins internistes.

Conclusions. La recherche a montré des connaissances insuffisantes des médecins résidents des professions médicales de différentes spécialités sur l'IDP. La faiblesse identifiée dans l'enseignement et la formation des médecins internes dans le domaine de l'IDP aideront à améliorer les programmes éducatifs qui peuvent aider au diagnostic précoce, à superviser les patients et améliorer la qualité de vie des enfants avec l'IDP.

Mots-clés: immunodéficience primaire, la compétence des médecins résidents, pédiatres.

remains difficult ${ }^{8,9}$. A large number of PID are undiagnosed or misdiagnosed. An important challenge is the awareness of young doctors about this problem ${ }^{3}$. One of the reasons for the significantly increasing number of patients with diagnosed PID is expanding education and awareness initiatives ${ }^{2,6,10}$.

The obJective OF THE Study was to evaluate the knowledge about primary immunodeficiencies among postgraduate medical students of different specialties.

\section{Material AND MEthods}

We conducted a survey among postgraduate medical students (interns) of different specialties on the awareness of PID. The study involved postgraduate medical students of I. Horbachevsky Ternopil State Medical University, Ukraine. The survey was conducted between September $1^{\text {st }}$ and December $30^{\text {th }}, 2017$. The questionnaires were offered to 93 postgraduate medical students. All of them agreed to answer the questions. There were 93 participants: 17 pediatricians, 27 general practitioners/ family (GP/F) physicians, 39 internists, 10 surgeons. The questionnaires were distributed on-site during working hours. 
The survey included a questionnaire with 25 questions (Table 1). The questionnaire can be divided into four sections: warning signs in children (4 questions) and in adults (2 questions); general signs of PID (5 questions); specific signs of PID (9 questions); treatment strategies and immunization of patients with PID (5 questions). The questionnaire was drawn up by immunologists. Most questions supposed the answers 'true' or 'false'. Two questions had two possible answers and two questions had three ones. In total, the physicians had to give 31 answers.

The verbal consent was obtained before conducting the questionnaire survey; the participants were informed about the reasons why the information was collected and how it would be used. Prior to handling the questionnaire, a statement was read to participants, informing them that their participation was voluntary and assuring that their answers were anonymous and confidential.

Table 1. Percentage of correct answers given by the surveyed postgraduate students $(n=93)$ taking part in the study.

\begin{tabular}{|c|c|c|c|c|c|c|c|c|c|c|c|}
\hline \multirow[t]{2}{*}{$N$} & \multirow[t]{2}{*}{ Questions } & \multicolumn{2}{|c|}{$\begin{array}{l}\text { Pediatricians } \\
\quad(n=17)\end{array}$} & \multicolumn{2}{|c|}{$\begin{array}{l}\text { GP / F physi- } \\
\text { cians }(n=27)\end{array}$} & \multicolumn{2}{|c|}{$\begin{array}{c}\text { Internists } \\
(n=39)\end{array}$} & \multicolumn{2}{|c|}{$\begin{array}{c}\text { Surgeons } \\
(n=10)\end{array}$} & \multicolumn{2}{|c|}{$\begin{array}{c}\text { Total } \\
(n=93)\end{array}$} \\
\hline & & $n$ & $\%$ & $n$ & $\%$ & $n$ & $\%$ & $n$ & $\%$ & $n$ & $\%$ \\
\hline 1. & PID occur only in children & 13 & 74.5 & 21 & 77.8 & 16 & 41.0 & 2 & 20.0 & 52 & 55.9 \\
\hline 2. & $\begin{array}{l}\text { Telangiectasia may be specific to: } \\
\text { A) hepatic insufficiency, } \\
\text { б) ataxia-telangiectasia syndrome } \\
\text { (Louis-Bar's syndrome) }\end{array}$ & $\begin{array}{l}17 \\
13 \\
\end{array}$ & $\begin{array}{r}100 \\
74.5 \\
\end{array}$ & $\begin{array}{l}26 \\
13 \\
\end{array}$ & $\begin{array}{l}96.3 \\
48.1 \\
\end{array}$ & $\begin{array}{l}35 \\
20 \\
\end{array}$ & $\begin{array}{l}89.7 \\
51.3 \\
\end{array}$ & $\begin{array}{l}4 \\
8 \\
\end{array}$ & $\begin{array}{l}40.0 \\
80.0\end{array}$ & $\begin{array}{l}82 \\
54 \\
\end{array}$ & $\begin{array}{l}88.2 \\
58.1 \\
\end{array}$ \\
\hline 3. & $\begin{array}{l}\text { The absence of thymus confirms Di } \\
\text { George syndrome }\end{array}$ & 11 & 64.7 & 21 & 77.8 & 25 & 64.1 & 6 & 60.0 & 63 & 67.7 \\
\hline 4. & $\begin{array}{l}\text { Common variable immunodeficiency } \\
\text { (CVID) is most often diagnosed in } \\
\text { children }\end{array}$ & 3 & 17.6 & 7 & 25.9 & 13 & 33.3 & 0 & 0 & 23 & 24.7 \\
\hline 5. & $\begin{array}{l}\text { Oncological diseases can be a sign } \\
\text { of PID }\end{array}$ & 15 & 88.2 & 22 & 81.5 & 28 & 71.8 & 9 & 90.0 & 74 & 79.6 \\
\hline 6. & $\begin{array}{l}\text { AFP (alpha-fetoprotein) appears in } \\
\text { high concentrations in A-T syndrome }\end{array}$ & 12 & 70.6 & 21 & 77.8 & 25 & 64.1 & 6 & 60.0 & 64 & 68.8 \\
\hline 7. & $\begin{array}{l}\text { Four or more new ear infections } \\
\text { within } 1 \text { year may be a warning sign } \\
\text { of PID }\end{array}$ & 17 & 100 & 5 & 18.5 & 25 & 64.1 & 8 & 80.0 & 55 & 59.1 \\
\hline 8. & $\begin{array}{l}\text { Failure of a child to gain weight } \\
\text { normally may be a sign of PID }\end{array}$ & 17 & 100 & 25 & 92.6 & 23 & 59.0 & 7 & 70.0 & 72 & 77.4 \\
\hline 9. & $\begin{array}{l}\text { Repeated abscesses of skin and } \\
\text { organs (without damage to the tissue } \\
\text { integrity caused by trauma) may be a } \\
\text { sign of PID }\end{array}$ & 17 & 100 & 24 & 88.9 & 31 & 79.5 & 9 & 90.0 & 81 & 87.1 \\
\hline 10. & $\begin{array}{l}\text { Numerous (6 and more) of 'cof- } \\
\text { fee-with-milk' colored spots are } \\
\text { specific to: } \\
\text { A) Nijmegen breakage syndrome } \\
\text { (NBS) }\end{array}$ & 12 & 70.6 & 22 & 81.5 & 32 & 82.1 & 2 & 20.0 & 68 & 73.1 \\
\hline & $\begin{array}{l}\text { б) Louis-Bar's syndrome } \\
\text { B) Bruton's agammaglobulinemia }\end{array}$ & $\begin{array}{c}15 \\
8\end{array}$ & $\begin{array}{l}88.2 \\
47.1\end{array}$ & $\begin{array}{c}9 \\
20\end{array}$ & $\begin{array}{l}33.3 \\
74.1\end{array}$ & $\begin{array}{c}9 \\
22\end{array}$ & $\begin{array}{l}23.1 \\
56.4\end{array}$ & $\begin{array}{l}6 \\
4\end{array}$ & $\begin{array}{l}60.0 \\
40.0\end{array}$ & $\begin{array}{l}39 \\
54\end{array}$ & $\begin{array}{l}41.9 \\
58.1\end{array}$ \\
\hline 11. & $\begin{array}{l}\text { Two or more cases of pneumonia in a } \\
\text { year may be the only clinical manifes- } \\
\text { tation of PID }\end{array}$ & 9 & 52.9 & 22 & 81.5 & 20 & 51.3 & 9 & 90.0 & 60 & 64.5 \\
\hline 12. & $\begin{array}{l}\text { Four or more episodes of infection } \\
\text { (otitis, bronchitis, pneumonia) in an } \\
\text { adult patient may be a sign of PID }\end{array}$ & 12 & 70.6 & 25 & 92.6 & 35 & 89.7 & 9 & 90.0 & 81 & 87.1 \\
\hline 13. & $\begin{array}{l}\text { In adults, two or more cases of pneu- } \\
\text { monia (radiographically confirmed) } \\
\text { within three years may be a sign of } \\
\text { PID }\end{array}$ & 4 & 23.5 & 8 & 29.6 & 15 & 38.5 & 7 & 70.0 & 34 & 36.6 \\
\hline 14. & $\begin{array}{l}\text { Children diagnosed with microceph- } \\
\text { aly should undergo genetic testing }\end{array}$ & 4 & 23.5 & 2 & 7.4 & 16 & 41.0 & 4 & 40.0 & 26 & 28.0 \\
\hline
\end{tabular}


Table 1. Percentage of correct answers given by the surveyed postgraduate students $(n=93)$ taking part in the study. (continuare)

\begin{tabular}{|c|c|c|c|c|c|c|c|c|c|c|c|}
\hline \multirow[t]{2}{*}{$N$} & \multirow[t]{2}{*}{ Questions } & \multicolumn{2}{|c|}{$\begin{array}{c}\text { Pediatricians } \\
(n=17)\end{array}$} & \multicolumn{2}{|c|}{$\begin{array}{l}\text { GP / F physi- } \\
\text { cians }(n=27)\end{array}$} & \multicolumn{2}{|c|}{$\begin{array}{c}\text { Internists } \\
(n=39)\end{array}$} & \multicolumn{2}{|c|}{$\begin{array}{c}\text { Surgeons } \\
(n=10)\end{array}$} & \multicolumn{2}{|c|}{$\begin{array}{c}\text { Total } \\
(n=93) \\
\end{array}$} \\
\hline & & $n$ & $\%$ & $n$ & $\%$ & $n$ & $\%$ & $n$ & $\%$ & $n$ & $\%$ \\
\hline 15. & $\begin{array}{l}\text { Infections with atypical localization } \\
\text { or caused by atypical pathogens may } \\
\text { be a sign of PID }\end{array}$ & 14 & 82.4 & 24 & 88.9 & 31 & 79.5 & 8 & 80.0 & 77 & 82.7 \\
\hline 16. & $\begin{array}{l}\text { Dysmorphic facial features are } \\
\text { specific to: } \\
\text { A) common variable immunodefi- } \\
\text { ciency (CVID) } \\
\text { b) DiGeorge syndrome } \\
\text { c) Nijmegen breakage syndrome }\end{array}$ & $\begin{array}{l}10 \\
13 \\
12 \\
\end{array}$ & $\begin{array}{l}58.8 \\
74.5 \\
70.6 \\
\end{array}$ & $\begin{array}{c}1 \\
17 \\
6 \\
\end{array}$ & $\begin{array}{l}3.7 \\
63.0 \\
22.2 \\
\end{array}$ & $\begin{array}{l}12 \\
17 \\
16 \\
\end{array}$ & $\begin{array}{l}30.7 \\
43.6 \\
41.0 \\
\end{array}$ & $\begin{array}{l}5 \\
6 \\
4 \\
\end{array}$ & $\begin{array}{l}50.0 \\
60.0 \\
40.0 \\
\end{array}$ & $\begin{array}{l}28 \\
53 \\
38 \\
\end{array}$ & $\begin{array}{l}30.1 \\
57.0 \\
40.9 \\
\end{array}$ \\
\hline 17. & $\begin{array}{l}\text { The only method of treatment for } \\
\text { PID with antibody deficiency is } \\
\text { therapy with intravenous or subcuta- } \\
\text { neous immunoglobulin agents }\end{array}$ & 17 & 100 & 25 & 92.6 & 37 & 94.9 & 6 & 60.0 & 85 & 91.4 \\
\hline 18. & $\begin{array}{l}\text { Normal levels of leukocytes (WBC), } \\
\text { hemoglobin, platelets, HCT are suf- } \\
\text { ficient to exclude neutropenia }\end{array}$ & 13 & 74.5 & 7 & 25.9 & 24 & 61.5 & 4 & 40.0 & 48 & 51.6 \\
\hline 19. & $\begin{array}{l}\text { Live vaccines are contraindicated for } \\
\text { patients with NBS }\end{array}$ & 14 & 82.4 & 24 & 88.9 & 36 & 92.3 & 8 & 80.0 & 82 & 87.1 \\
\hline 20. & $\begin{array}{l}\text { Inflammation+ thrombocytopenia + } \\
\text { eczema may be the signs of: } \\
\text { A) Wiskott-Aldrich syndrome } \\
\text { b) atopic dermatitis }\end{array}$ & $\begin{array}{l}16 \\
11 \\
\end{array}$ & $\begin{array}{l}94.1 \\
64.7 \\
\end{array}$ & $\begin{array}{c}22 \\
9 \\
\end{array}$ & $\begin{array}{l}81.5 \\
33.3 \\
\end{array}$ & $\begin{array}{l}27 \\
24 \\
\end{array}$ & $\begin{array}{l}69.2 \\
61.5 \\
\end{array}$ & $\begin{array}{l}7 \\
8 \\
\end{array}$ & $\begin{array}{l}70.0 \\
80.0 \\
\end{array}$ & $\begin{array}{l}72 \\
52 \\
\end{array}$ & $\begin{array}{l}77.4 \\
55.9 \\
\end{array}$ \\
\hline 21. & $\begin{array}{l}\text { In cases of Nijmegen syndrome chest } \\
\text { X-ray examination is allowed }\end{array}$ & 9 & 52.9 & 18 & 66.7 & 16 & 41.0 & 6 & 60.0 & 49 & 52.7 \\
\hline 22. & $\begin{array}{l}\text { Live vaccines can be administered to } \\
\text { children with severe PID }\end{array}$ & 15 & 88.2 & 24 & 88.9 & 32 & 82.1 & 6 & 60.0 & 77 & 82.8 \\
\hline 23. & $\begin{array}{l}\text { Vaccination against pneumococcus } \\
\text { should be given to children with PID } \\
\text { that have retained the ability to synthe- } \\
\text { size antibodies (within the risk group) }\end{array}$ & 15 & 88.2 & 22 & 81.5 & 23 & 59.0 & 4 & 40.0 & 64 & 68.8 \\
\hline 24. & $\begin{array}{l}\text { All adults with primary and second- } \\
\text { ary asplenia should be vaccinated } \\
\text { against pneumococcus and meningo- } \\
\text { coccus }\end{array}$ & 15 & 88.2 & 22 & 81.5 & 30 & 76.9 & 4 & 40.0 & 71 & 76.3 \\
\hline 25. & $\begin{array}{l}\text { Autoimmune diseases are much more } \\
\text { common in patients with PID }\end{array}$ & 12 & 70.6 & 24 & 88.9 & 27 & 69.2 & 4 & 40.0 & 67 & 72.0 \\
\hline & Total: & 405 & 76.9 & 507 & 60.6 & 742 & 61.4 & 180 & 58.1 & 1834 & 63.6 \\
\hline
\end{tabular}

The ethical approval for the study was provided by the scientific ethics committee of I. Horbachevsky Ternopil State Medical University. The study conformed to the principles outlined in the WMA Declaration of Helsinki.

The results were analysed using standard procedures with Statistica StatSoft 6.0 software package. The distribution of variables was assessed by Chi-square test and the Fisher's exact test. The significance level of the tests was set at $\alpha=0.05$.

\section{Results}

The age of the respondents ranged from 24 to 32 years. Women dominated among surveyed postgraduate medical students (79.6\%). The list of the questions and percentage of correct answers of all the respondents and depending on the specialty are presented in Table 1. The average percentage of correct answers given by the surveyed postgraduate medical students was $63.6 \%$, and ranged from $24.7 \%$ to $91.4 \%$. The analysis of the data showed that the highest level of knowledge was demonstrated by pediatricians (76.9\% of correct answers). A significant less level of knowledge was demonstrated by the postgraduate medical students of other specialties in comparison with pediatricians: GP/F physicians $(\mathrm{p}=0.0061)$, internists $(\mathrm{p}=0.0054)$, surgeons $(\mathrm{p}=0.0144)$.

The percentage of correct answers given by the physicians depending on their specialties is presented 
Table 2. Number and percentage of the surveyed physicians, depending on percentages of correct answers.

\begin{tabular}{|c|c|c|c|c|c|c|c|c|c|c|}
\hline \multirow{2}{*}{$\%$ of correct answers } & \multicolumn{2}{|c|}{ Pediatricians } & \multicolumn{2}{|c|}{ GP/F physicians } & \multicolumn{2}{|c|}{ Internists } & \multicolumn{2}{|c|}{ Surgeons } & \multicolumn{2}{|c|}{ Total } \\
\hline & $n$ & $\%$ & $n$ & $\%$ & $n$ & $\%$ & $n$ & $\%$ & $n$ & $\%$ \\
\hline $50-74$ & 11 & 64.7 & 26 & 96.3 & 34 & 87.2 & 10 & 100 & 81 & 87.1 \\
\hline $75-90$ & 6 & 35.3 & 1 & 3.7 & 5 & 12.8 & - & & 12 & 12.9 \\
\hline
\end{tabular}

Table 3. Percentage of correct answers to the questions about warning signs in children and adults.

\begin{tabular}{|c|c|c|c|c|c|c|c|c|c|c|c|}
\hline \multirow{3}{*}{ No. } & \multirow{3}{*}{ Question } & \multirow{2}{*}{\multicolumn{2}{|c|}{$\begin{array}{c}\text { Pediatricians } \\
n=17 \\
\end{array}$}} & \multirow{2}{*}{\multicolumn{2}{|c|}{$\begin{array}{c}\text { GP/F physicians } \\
n=27\end{array}$}} & \multirow{2}{*}{\multicolumn{2}{|c|}{$\begin{array}{c}\text { Internists } \\
n=39\end{array}$}} & \multirow{2}{*}{\multicolumn{2}{|c|}{$\begin{array}{c}\text { Surgeons } \\
n=10\end{array}$}} & \multirow{2}{*}{\multicolumn{2}{|c|}{$\begin{array}{l}\text { Total } \\
n=93 \\
\end{array}$}} \\
\hline & & & & & & & & & & & \\
\hline & & $n$ & $\%$ & $n$ & $\%$ & $n$ & $\%$ & $n$ & $\%$ & $n$ & $\%$ \\
\hline & Warning signs in children & 60 & 88.2 & 76 & 70.4 & 99 & 63.5 & 33 & 82.5 & 268 & 72.0 \\
\hline 1. & $\begin{array}{l}\text { Four or more new ear infec- } \\
\text { tions within } 1 \text { year may be a } \\
\text { warning sign of PID }\end{array}$ & 17 & 100 & 5 & 18.5 & 25 & 64.1 & 8 & 80.0 & 55 & 59.1 \\
\hline 2. & $\begin{array}{l}\text { Failure of a child to gain } \\
\text { weight normally may be a } \\
\text { sign of PID }\end{array}$ & 17 & 100 & 25 & 92.6 & 23 & 59.0 & 7 & 70.0 & 72 & 77.4 \\
\hline 3. & $\begin{array}{l}\text { Two or more cases of pneu- } \\
\text { monia in a year may be the } \\
\text { only clinical manifestation } \\
\text { of PID }\end{array}$ & 9 & 52.9 & 22 & 81.5 & 20 & 51.3 & 9 & 90.0 & 60 & 64.5 \\
\hline \multirow[t]{2}{*}{4.} & $\begin{array}{l}\text { Repeated abscesses of skin } \\
\text { and organs (without damage } \\
\text { to the tissue integrity caused } \\
\text { by trauma) may be a sign of } \\
\text { PID }\end{array}$ & 17 & 100 & 24 & 88.9 & 31 & 79.5 & 9 & 90.0 & 81 & 87.1 \\
\hline & Warning signs in adults & 16 & 47.1 & 33 & 61.1 & 50 & 64.1 & 16 & 80.0 & 115 & 61.8 \\
\hline 1. & $\begin{array}{l}\text { Four or more episodes of } \\
\text { infection (otitis, bronchitis, } \\
\text { pneumonia) in an adult pa- } \\
\text { tient may be a sign of PID }\end{array}$ & 12 & 70.6 & 25 & 92.6 & 35 & 89.7 & 9 & 90.0 & 81 & 87.1 \\
\hline 2. & $\begin{array}{l}\text { In adults, two or more cases } \\
\text { of pneumonia (radiographi- } \\
\text { cally confirmed) within three } \\
\text { years may be a sign of PID }\end{array}$ & 4 & 23.5 & 8 & 29.6 & 15 & 38.5 & 7 & 70.0 & 34 & 36.6 \\
\hline
\end{tabular}

in Table 2. All postgraduate medical students gave above $50 \%$ of correct answers. However, the percentage of the answers given by surgeons was limited to $50-74 \%$. Twelve $(12.9 \%)$ interns of other specialties had answered more than $75 \%$ of the questions correctly, half of them were pediatricians.

The number of correct answers to the questions about the warning signs of PID in children and adults is presented in Table 3. The postgraduate medical students demonstrated an average knowledge of the warning signs of PID in children and adults. The percentage of the correct answers about warning signs in children was $72.0 \%$, and it ranged from $63.5 \%$ among internists to $88.2 \%$ among pediatricians. The percentage of the correct answers about warning signs in adults was $61.8 \%$, and it ranged from $47.1 \%$ among pediatricians to $80.0 \%$ among surgeons.

Poor knowledge was demonstrated by pediatricians and internists on two or more cases of pneumonia as clinical manifestation of PID, while GP/F physicians demonstrated lack of knowledge on repeated ear infections. Unfortunately, only $36.6 \%$ of postgraduate medical students gave the correct answer to the question about pneumonia as a clinical manifestation of PID in adults. GP/F physicians, internists and pediatricians show lack of sufficient awareness of PID warning signs in adults.

The answers to the questions about general signs of PID are presented in Table 4. The majority of internists and surgeons reported that PID are found only in children. The majority of postgraduate medical students of surveyed specialties and all surgeons convinced that CVID is most often diagnosed in children. The interns demonstrated better knowledge concerning general signs of PIDs, such as oncological pathology, and atypical infections. The percentage of correct answers to these questions ranged from $71.8 \%$ to $90.0 \%$, with no 
Archives of the Balkan Medical Union

Table 4. Percentage of correct answers to the questions about general signs of PID.

\begin{tabular}{|c|c|c|c|c|c|c|c|c|c|c|c|}
\hline \multirow{3}{*}{ No. } & \multirow{3}{*}{ Question } & \multirow{2}{*}{\multicolumn{2}{|c|}{$\begin{array}{c}\text { Pediatricians } \\
n=17\end{array}$}} & \multirow{2}{*}{\multicolumn{2}{|c|}{$\begin{array}{c}\text { GP/F physicians } \\
n=27\end{array}$}} & \multirow{2}{*}{\multicolumn{2}{|c|}{$\begin{array}{c}\text { Internists } \\
n=39\end{array}$}} & \multirow{2}{*}{\multicolumn{2}{|c|}{$\begin{array}{c}\text { Surgeons } \\
n=10\end{array}$}} & \multirow{2}{*}{\multicolumn{2}{|c|}{$\begin{array}{l}\text { Total } \\
n=93\end{array}$}} \\
\hline & & & & & & & & & & & \\
\hline & & $n$ & $\%$ & $n$ & $\%$ & $n$ & $\%$ & $n$ & $\%$ & $n$ & $\%$ \\
\hline 1. & PID occur only in children & 13 & 74.5 & 21 & 77.8 & 16 & 41.0 & 2 & 20.0 & 52 & 55.9 \\
\hline 2. & $\begin{array}{l}\text { Common variable immunode- } \\
\text { ficiency (CVID) is most often } \\
\text { diagnosed in children }\end{array}$ & 3 & 17.6 & 7 & 25.9 & 13 & 33.3 & 0 & 0 & 23 & 24.7 \\
\hline 3. & $\begin{array}{l}\text { Oncological diseases can be a } \\
\text { sign of PID }\end{array}$ & 15 & 88.2 & 22 & 81.5 & 28 & 71.8 & 9 & 90.0 & 74 & 79.6 \\
\hline 4. & $\begin{array}{l}\text { Autoimmune diseases are } \\
\text { much more common in pa- } \\
\text { tients with PID }\end{array}$ & 12 & 70.6 & 24 & 88.9 & 27 & 69.2 & 4 & 40.0 & 67 & 72.0 \\
\hline 5. & $\begin{array}{l}\text { Infections with atypical lo- } \\
\text { calization or caused by atypical } \\
\text { pathogens may be a sign of PID }\end{array}$ & 14 & 82.4 & 24 & 88.9 & 31 & 79.5 & 8 & 80.0 & 77 & 82.7 \\
\hline & Total & 57 & 67.1 & 98 & 72.6 & 115 & 59.0 & 23 & 46.0 & 293 & 63.0 \\
\hline
\end{tabular}

Table 5. Percentage of correct answers to the questions about specific signs of PID.

\begin{tabular}{|c|c|c|c|c|c|c|c|c|c|c|c|}
\hline \multirow{3}{*}{ N } & \multirow{3}{*}{ Question } & \multirow{2}{*}{\multicolumn{2}{|c|}{$\begin{array}{c}\text { Pediatricians } \\
n=17\end{array}$}} & \multirow{2}{*}{\multicolumn{2}{|c|}{$\begin{array}{c}\text { GP/F physicians } \\
n=27\end{array}$}} & \multirow{2}{*}{\multicolumn{2}{|c|}{$\begin{array}{c}\text { Internists } \\
n=39\end{array}$}} & \multirow{2}{*}{\multicolumn{2}{|c|}{$\begin{array}{c}\text { Surgeons } \\
n=10\end{array}$}} & \multirow{2}{*}{\multicolumn{2}{|c|}{$\begin{array}{l}\text { Total } \\
n=93\end{array}$}} \\
\hline & & & & & & & & & & & \\
\hline & & $n$ & $\%$ & $n$ & $\%$ & $n$ & $\%$ & $n$ & $\%$ & $n$ & $\%$ \\
\hline 1. & $\begin{array}{l}\text { Telangiectasia may be specific to: } \\
\text { A) hepatic insufficiency, } \\
\text { б) ataxia-telangiectasia syndrome } \\
\text { (Louis-Bar's syndrome) }\end{array}$ & $\begin{array}{l}17 \\
13 \\
\end{array}$ & $\begin{array}{l}100 \\
74.5\end{array}$ & $\begin{array}{l}26 \\
13 \\
\end{array}$ & $\begin{array}{l}96.3 \\
48.1\end{array}$ & $\begin{array}{l}35 \\
20\end{array}$ & $\begin{array}{l}89.7 \\
51.3\end{array}$ & $\begin{array}{l}4 \\
8\end{array}$ & $\begin{array}{l}40.0 \\
80.0\end{array}$ & $\begin{array}{l}82 \\
54\end{array}$ & $\begin{array}{l}88.2 \\
58.1\end{array}$ \\
\hline 2. & $\begin{array}{l}\text { The absence of thymus confirms } \\
\text { Di George syndrome }\end{array}$ & 11 & 64.7 & 21 & 77.8 & 25 & 64.1 & 6 & 60.0 & 63 & 67.7 \\
\hline 3. & $\begin{array}{l}\text { Numerous ( } 6 \text { and more) of } \\
\text { 'coffee-with-milk' colored spots } \\
\text { are specific to: } \\
\text { A) Nijmegen breakage syndrome } \\
\text { (NBS) }\end{array}$ & 12 & 70.6 & 22 & 81.5 & 32 & 82.1 & 2 & 20.0 & 68 & 73.1 \\
\hline & $\begin{array}{l}\text { б) Louis-Bar syndrome } \\
\text { B) Bruton's agammaglobulinemia }\end{array}$ & $\begin{array}{c}15 \\
8\end{array}$ & $\begin{array}{l}88.2 \\
47.1 \\
\end{array}$ & $\begin{array}{c}9 \\
20 \\
\end{array}$ & $\begin{array}{l}33.3 \\
74.1 \\
\end{array}$ & $\begin{array}{c}9 \\
22 \\
\end{array}$ & $\begin{array}{l}23.1 \\
56.4\end{array}$ & $\begin{array}{l}6 \\
4 \\
\end{array}$ & $\begin{array}{l}60.0 \\
40.0\end{array}$ & $\begin{array}{l}39 \\
54\end{array}$ & $\begin{array}{l}41.9 \\
58.1\end{array}$ \\
\hline 4. & $\begin{array}{l}\text { Dysmorphic facial features are } \\
\text { specific to: } \\
\text { A) common variable immunode- } \\
\text { ficiency (CVID) }\end{array}$ & 10 & 58.8 & 1 & 3.7 & 12 & 30.7 & 5 & 50.0 & 28 & 30.1 \\
\hline & $\begin{array}{l}\text { b) DiGeorge syndrome } \\
\text { c) Nijmegen breakage syndrome }\end{array}$ & $\begin{array}{l}13 \\
12\end{array}$ & $\begin{array}{l}74.5 \\
70.6\end{array}$ & $\begin{array}{c}17 \\
6\end{array}$ & $\begin{array}{l}63.0 \\
22.2\end{array}$ & $\begin{array}{l}17 \\
16\end{array}$ & $\begin{array}{l}43.6 \\
41.0\end{array}$ & $\begin{array}{l}6 \\
4\end{array}$ & $\begin{array}{l}60.0 \\
40.0\end{array}$ & $\begin{array}{l}53 \\
38\end{array}$ & $\begin{array}{l}57.0 \\
40.9\end{array}$ \\
\hline
\end{tabular}

5. Inflammation+ thrombocytopenia + eczema may be the signs of:
A) Wiskott Aldrich syndrome

b) atopic dermatitis

$\begin{array}{llllllllll}16 & 94.1 & 22 & 81.5 & 27 & 69.2 & 7 & 70.0 & 72 & 77.4\end{array}$

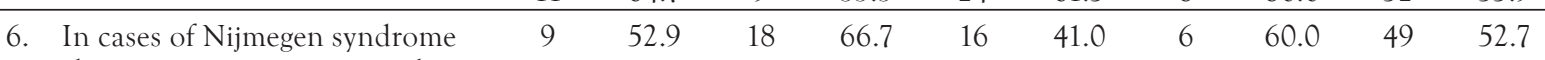
chest X-ray examination is allowed

$\begin{array}{llllllllllll}\text { 7. } & \text { Normal levels of leukocytes } & 13 & 74.5 & 7 & 25.9 & 24 & 61.5 & 4 & 40.0 & 48 & 51.6\end{array}$ (WBC), hemoglobin, platelets,

HCT are sufficient to exclude neutropenia

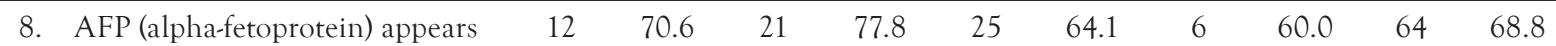
in high concentrations in A-T syndrome

9. Children diagnosed with micro- $\quad \begin{array}{lllllllllll} & 4 & 23.5 & 2 & 7.4 & 16 & 41.0 & 4 & 40.0 & 26 & 28.0\end{array}$ cephaly should undergo genetic testing

Total:

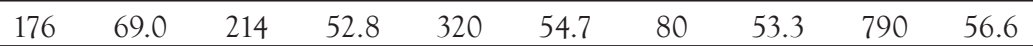


significant differences between doctors of various specialties.

The number of correct answers to the questions about specific signs of certain PIDs depending on postgraduate medical students' specialty is presented in Table 5. The percentage of correct answers to the questions about specific signs of certain PID ranged from $3.7 \%$ to $100 \%$. The best overall knowledge was demonstrated by pediatricians $(69.0 \%$ of correct answers). It was significantly better than among GP/F physicians $(p=0.0388)$. The poor knowledge was demonstrated about specific signs to A-T syndrome: telangiectasia (the total percentage 58.1\%) and 'coffee-with-milk' colored spots (the total percentage $41.9 \%$ ). The worst knowledge was revealed among GP/F physicians and internists.

The total percentage of the correct answers about dysmorphic facial features specific to some PID was low and ranged from $30.1 \%$ to $57 \%$. The worst knowledge was demonstrated among GP/F physicians, especially about CVID. Poor knowledge was shown among internists and surgeons. Some difficulties with distinguishing the signs and appropriate management of NBS were determined among the postgraduate medical students, even among pediatricians.

The analysis of the answers to the questions about treatment and immunization of children with PID and with reference to the specialties are presented in Table 6 . The average percentage of correct answers to the questions about vaccination was more than $56 \%$ in all groups of interns.

\section{Discussion}

Education and awareness are significant tools for early diagnosis of PID ${ }^{10-12}$. Evaluation of physicians' knowledge and awareness about PID underscore the areas in which improved educational and training initiatives may benefit of patient care and life quality of PID children ${ }^{13}$.

According to our research, the percentage of correct answers given by the surveyed postgraduate medical students was $63.6 \%$, and ranged from $24.7 \%$ to $91.4 \%$. The highest level of knowledge was demonstrated among interns-pediatricians (76.9\%), the lowest - among surgeons (58.1\%), $\mathrm{p}<0.05$. The evaluation of PID knowledge among pediatric residents in the State of Qatar demonstrated a percentage of correct answers of $58.6 \%$ of all questions ${ }^{14}$, which is slightly lower than in our study.

Other studies were conducted to evaluate knowledge of PID among doctors of different specialties ${ }^{15-17}$. They also demonstrated that pediatricians had much higher level of PID knowledge than other clinicians and surgeons ${ }^{15,16}$. However, the study among doctors of our region didn't found any significant difference in awareness on PID among pediatricians, GP/F physicians, surgical and pediatric specialists ${ }^{17}$.

It is very important for physicians to recognize the warning signs of PID, to be aware of the management of such patients. Other study revealed that $77 \%$ of physicians did not know the warning signs for PID ${ }^{15}$. According to our study, the percentage of correct

Table 6. Number and percentage of correct answers to the questions about treatment and vaccination of children with PID.

\begin{tabular}{|c|c|c|c|c|c|c|c|c|c|c|c|}
\hline \multirow{3}{*}{$N$} & \multirow{3}{*}{ Question } & \multirow{2}{*}{\multicolumn{2}{|c|}{$\begin{array}{c}\text { Pediatricians } \\
n=17\end{array}$}} & \multirow{2}{*}{\multicolumn{2}{|c|}{$\begin{array}{c}\text { GP/F physicians } \\
n=27\end{array}$}} & \multirow{2}{*}{\multicolumn{2}{|c|}{$\begin{array}{c}\text { Internists } \\
n=39\end{array}$}} & \multirow{2}{*}{\multicolumn{2}{|c|}{$\begin{array}{c}\text { Surgeons } \\
n=10\end{array}$}} & \multirow{2}{*}{\multicolumn{2}{|c|}{$\begin{array}{l}\text { Total } \\
n=93 \\
\end{array}$}} \\
\hline & & & & & & & & & & & \\
\hline & & $n$ & $\%$ & $n$ & $\%$ & $n$ & $\%$ & $n$ & $\%$ & $n$ & $\%$ \\
\hline 1. & $\begin{array}{l}\text { The only method of treatment for } \\
\text { PID with antibody deficiency is } \\
\text { therapy with intravenous or subcu- } \\
\text { taneous immunoglobulin agents }\end{array}$ & 17 & 100 & 25 & 92.6 & 37 & 94.9 & 6 & 60.0 & 85 & 91.4 \\
\hline 2. & $\begin{array}{l}\text { Live vaccines are contraindicated } \\
\text { for patients with NBS }\end{array}$ & 14 & 82.4 & 24 & 88.9 & 36 & 92.3 & 8 & 80.0 & 82 & 87.1 \\
\hline 3. & $\begin{array}{l}\text { Live vaccines can be administered } \\
\text { to children with severe PID }\end{array}$ & 15 & 88.2 & 24 & 88.9 & 32 & 82.1 & 6 & 60.0 & 77 & 82.8 \\
\hline 4. & $\begin{array}{l}\text { Vaccination against pneumococcus } \\
\text { should be given to children with } \\
\text { PID that have retained the ability } \\
\text { to synthesize antibodies (within } \\
\text { the risk group) }\end{array}$ & 15 & 88.2 & 22 & 81.5 & 23 & 59.0 & 4 & 40.0 & 64 & 68.8 \\
\hline \multirow[t]{2}{*}{5.} & $\begin{array}{l}\text { All adults with primary and } \\
\text { secondary asplenia should be vac- } \\
\text { cinated against pneumococcus and } \\
\text { meningococcus }\end{array}$ & 15 & 88.2 & 22 & 81.5 & 30 & 76.9 & 4 & 40.0 & 71 & 76.3 \\
\hline & Total: & 76 & 89.4 & 117 & 86.7 & 158 & 81.0 & 28 & 56.0 & 379 & 81.5 \\
\hline
\end{tabular}


answers to the questions about warning signs in adults was less than in children (61.8\% versus $72.0 \%)$. A good knowledge was shown by pediatricians about the most warning signs of PID in children $(100 \%$ of correct answers), excepting the question about pneumonia (52.9\%). The worst knowledge about warning signs in children was demonstrated by internists (63.5\%), and questions about warning signs in adults were responded wrong by pediatricians (47.1\% correct answers).

A great percentage of postgraduate medical students didn't know that PID occurred in adults too, and that CVID was most often diagnosed in adults. The most disturbing fact was that majority of internists and surgeons believed that PID occurred only in children, and all of the surgeons, $74.1 \%$ of GP/F physicians and $66.7 \%$ of internists didn't know that CVID was mostly diagnosed in adults.

Insufficient knowledge was demonstrated by postgraduate medical students about the specific features and management of PID, especially about A-T syndrome and NBS. Thus, only $28.0 \%$ of interns indicated that children with microcephaly should be directed to genetic testing. Only $47.3 \%$ of interns knew that chest X-ray examination could be contraindicated for children with NBS.

The analysis of the data demonstrated that all postgraduate medical students knew quite well the treatment methods of PIDs with antibody deficiency and contraindications for administration of live vaccines. Poor knowledge about vaccination was revealed only among surgeons. One of the reasons for an insufficient knowledge and difficulties to diagnose and follow patients with PID could be due to the lack of immunology training during the residency ${ }^{14}$. Therefore, it is very important to develop knowledge about PID also in undergraduate students.

The physician's education and public awareness campaign provided by the Jeffrey Modell Foundation during last year confirms substantial benefits in improving early diagnosis, treatment and managing of children with PID $^{6,18}$. Implementation of such program in Central and Eastern Europe ( $\mathrm{J}$ - Project) showed a significant increase in the number of PID recognition ${ }^{19}$.

\section{Conclusions}

The study has shown insufficient knowledge of primary immunodeficiencies among postgraduate medical students of different specialties. The highest level of knowledge was demonstrated among pediatricians. The poor awareness was revealed concerning the specific signs of PID, in particular verification of ataxia-telangiectasia and management of Nijmegen breakage syndrome. Identified weaknesses in educating and training of postgraduate medical students about PID will help to enhance the educational programs that may benefit of early diagnosis, patient management and improve quality of life of children with PID.

\section{Compliance with Ethics Requirements:}

„The authors declare no conflict of interest regarding this article"

"The authors declare that all the procedures and experiments of this study respect the ethical standards in the Helsinki Declaration of 1975, as revised in 2008(5), as well as the national law. Informed consent was obtained from all the participants included in the study"

Acknowledgments: The authors wish to thank Jeffrey Modell Foundation for the financial support of this study.

\section{References}

1. Bousfiha AA, Jeddane L, Ailal F, et al. Primary immunodeficiency diseases worldwide: more common than generally thought. Journal of Clinical Immunology 2013;33(1):1-7.

2. Modell V, Orange JS, Quinn J, Modell F. Global report on primary immunodeficiencies: 2018 update from the Jeffrey Modell Centers Network on disease classification, regional trends, treatment modalities, and physician reported outcomes. Immunologic Research 2018;66:367-380.

3. Modell V, Knaus M, Modell F, et al. Global overview of primary immunodeficiencies: a report from Jeffrey Modell Centers worldwide focused on diagnosis, treatment, and discovery. Immunologic Research 2014;60(1):132-144.

4. Boyarchuk O, Volyanska L, Dmytrash L. Clinical variability of chromosome 22q11.2 deletion syndrome. Central European Journal of Immunology 2017;42(4):412-417.

5. Modell V, Quinn J, Ginsberg G, et al. Modeling strategy to identify patients with primary immunodeficiency utilizing risk management and outcome measurement. Immunologic Research 2017: 65:713.

6. Modell F, Puente D, Modell V. From genotype to phenotype. Further studies measuring the impact of a Physician Education and Public Awareness Campaign on early diagnosis and management of primary immunodeficiencies. Immunologic Research 2009;44(1):132-149.

7. Mohammadzadeh I, Moazzami B, Ghaffari J, et al. Primary immunodeficiency diseases in Northern Iran. Allergologia et Immunopathologia 2017;45(3):244-250.

8. Chernyshova LI, Bondarenko AV, Kostyuchenko LV, et al. Epidemiology of primary immunodeficiencies in Ukraine according to the register of patients. Child's Health 2015;7(67):16-23.

9. Kinash M, Dmytrash L, Dzyuban L, et al. Structure of primary immunodeficiencies in Ternopil region of Ukraine. Central European Journal of Immunology 2014;39(11):14.

10. Modell V. The impact of physician education and public awareness on early diagnosis of primary immunodeficiencies. Immunologic Research 2007;38:43-7.

11. Espinosa-Rosales FJ, Condino-Neto A, Franco JL, et al. Into action: Improving access to optimum care for all primary 
immunodeficiency patients. Journal of Clinical Immunology 2016;36(5):415-417.

12. Hernandez-Trujillo VP, Scalchunes C, Hernandez-Trujillo HS, et al. Primary immunodeficiency diseases: an opportunity in pediatrics for improving patient outcomes. Clinical Pediatrics 2015;54(13):1265-75.

13. Orange JS, Seeborg FO, Boyle M, et al. Family physician perspectives on primary immunodeficiency diseases. Frontiers in Medicine 2016;30(3):12.

14. Adeli M, Hendaus M, Imam L, Alhammadi A. The importance of educating pediatricians about primary immunodeficiency disorders: a tertiary hospital experience. Georgian Medical News 2015;(246):66-72.

15. Dantas EO, Arandaa CS, Rego Silva AM, et al. Doctors' awareness concerning primary immunodeficiencies in Brazil. Allergol Immunopathol (Madr) 2015;43:272-8.
16. Nourijelyani K, Aghamohammadi A, Salehi Sadaghiani M, et al. Physicians awareness on primary immunodeficiency disorders in Iran. Iran Journal Allergy Asthma Immunology. 2012;11(1):57-64.

17. Boyarchuk O, Lewandowicz-Uszynska A, Kinash M, et al. Physicians' awareness concerning primary immunodeficiencies in Ternopil region, Ukraine. Pediatria Polska 2018;93 (3):221-228.

18. Joshi AY, Iyer VN, Hagan JB, et al. Incidence and temporal trends of primary immunodeficiency: a population-based cohort study. Mayo Clinic Proceedings 2009;84(1):16-22.

19. Marodi L, Casanova JL. Primary immunodeficiency diseases: the J project. Lancet 2009;373(9682):2179 -2181. 